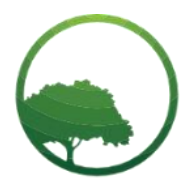

Research in Business \& Social Science

IJRBS VOL 11 NO 1 (2022) ISSN: 2147-4478

\title{
Are there legal consequences from procedural mistakes in handling child sexual abuse victims in Indonesia?
}

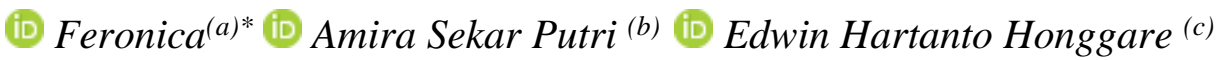 \\ ${ }^{(a, b, c)}$ Faculty of Law, Atma Jaya Catholic University of Indonesia, Jakarta, Indonesia
}

\author{
A R T I C L E I N F O \\ Article history: \\ Received 12 December 2021 \\ Received in rev. form 03 Feb. 2022 \\ Accepted 10 February 2022 \\ Keywords: \\ Procedure, handling, child, victim, \\ sexual violence \\ JEL Classification: \\ K10
}

\begin{abstract}
A B S T R A C T
The alleged rape case of a child at East Luwu in 2019 was terminated due to lack of evidence. Because of the news from mass media, the case was reopened in 2021 but was obstructed due to the need to wait for new evidence. This article does not discuss the evidence but highlights the procedure for handling child sexual victims that are used by several institutions. There are several institutions that can be involved in helping accompany and handle cases involving children as victims. At regional levels, there is the Integrated Service Center for the Empowerment of Women and Children (P2TP2A) whose duty is to give information, consultation on psychology and law, accompaniment and advocation, and services on medication and shelter. And the National Police of the Republic of Indonesia has the authority to start handling a criminal case. According to news from Vice.com, the case at North Luwu was originally reported by the victim's mother to The Integrated Service Center for The Empowerment of Women And Children East Luwu. The officer then summoned the victim's father who was the suspect. The officer reasoned that the mother's report needed to be confirmed. The victim's mother then reported the case to East Luwu Police Station. The police did an investigation, without the parents, law advisors, social workers, or even psychologists. This case then snowballed, and the evidence was put into question, without many highlights to the handling procedure that was used by The Integrated Service Center for The Empowerment of Women And Children officers and police force. How should the procedure on handling the child sexual victim have been done? If a mistake in the handling procedure occurred, are there any legal consequences? This article was developed as normative research, using statutory regulations, research results, and the opinion of law experts, as well as case progression from credible mass media.
\end{abstract}

(C) 2022 by the authors. Licensee SSBFNET, Istanbul, Turkey. This article is an open access article distributed under the terms and conditions of the Creative Commons Attribution (CC BY) license (http://creativecommons.org/licenses/by/4.0/).

\section{Introduction}

The alleged child rape case of three children by their father at Malili, East Luwu, in October 2019 was closed due to lack of evidence. The suspect was reported by his former wife, the mother of the three victims who were all under 10. The mother's suspicion was first aroused by her eldest child's behavior, who had become silent and closed off. On 7 October 2019, the youngest child complained to her mother of the pain in her vital organ and rectum. The middle child then said she had seen her older sibling "doing it" with their father. After checking and finding abnormalities on her children's anus' condition, the mother immediately reported to the Integrated service center for the empowerment of women and children East Luwu. However, the the integrated service center for the empowerment of women and children worker called in the suspect to "confirm her report". The mother then reported her former husband to East Luwu Police Station on 9 October 2019 (Zambon et al., 2012; Marbun et al., 2020; Daniati et al., 2021).

A female police officer took the three children for a viscum et repertum at a nearby public health center without any assistance. Then, the three were questioned by uniformed officers without being accompanied by their mother, legal counsel, social worker, or even a psychologist. The mother was then asked to sign the police investigation report but was forbidden from reading it first. 5 days later,

\footnotetext{
* Corresponding author.

(C) 2022 by the authors. Hosting by SSBFNET. Peer review under responsibility of Center for Strategic Studies in Business and Finance.

https://doi.org/10.20525/ijrbs.v11i1.1598
}

Citation: Feronica, Putri, A. S., \& Honggare, E. H. (2022). Are there legal consequences from procedural mistakes in handling child sexual abuse victims in Indonesia?. International Journal of Research in Business and Social Science (2147- 4478), 11(1). 
the report was received, and the police said it would be further investigated. The mother also gave a pair of bloodied pink panties as evidence on her own initiative.

On 18 October 2019, the police announced the result of the viscum et repertum. Nothing was found, they said. On the same day, the mother was interrogated without legal counsel. On 1 November 2019, the mother submitted further evidence in the form of a pair of pants with some green liquid on them and a pair of bloodied leggings. The investigation on the alleged child rape case went for 2 months before it was stopped in December 2019. The excuse being that there was no evidence of any immoral crime and that the integrated service center for the empowerment of women and children's investigations showed no signs of trauma for the three children to their father.

The case was then reopened in 2021 after it went viral on social media due to an article titled "My three children were raped, i reported to the police. the police stopped the investigation," that was found on projectmultatili.org on 6 October 2021. This investigation focused on the suspected time of the crime, which is the 25th to 31st of October 2019. It was known there were 2 versions of viscum et repertum reports, the earlier one which was done by the police on the 9th and 24th of October which showed no abnormalities, and the one done by the family on the 31 st of October when the abnormalities were found.

Other than sexual abuse case of a child that happened in East Luwu, another example also happened in Mamuju. The handling procedure was a bit different from the case in East Luwu because the perpetrator was caught on the spot by the neighborhood. The case happened in the beginning of this November, precisely on 1st November 2021 on Monday (Ghania \& Lathifah, 2022; Wuriani, 2021).

The case first happened in some neighborhood in Mamuju. The victim, who is a ten-year-old child, was playing with her friend of the same age in that neighborhood. While they were playing the perpetrator called and brought her to enter his rented room. In that room, the perpetrator (SU) intended to rape her (Chan, 2009).

She refused and screamed to ask for help. The neighborhood heard her scream and rushed to the perpetrator rented room and prevent sexual abuse to happen. They caught him while he wanted to rape her, pulled him out, and started to hit him. While hitting the perpetrator, one of them called the police to further for investigation. After the police arrived, they secured the evidence which one of them is the clothes that perpetrator was wearing while he wanted to rape the victim. The perpetrator is now already arrested in a cell in Mamuju Police.

Because of this, the victim has a traumatic to interact with other people. She even refused to play again with her friends. The police asked the office of women and children empowerment and protection of mamuju regency to assist the victim overcome her trauma. She will also be assisted by a psychologist during the healing process.

Based on both cases, there are several institutions that belong to Indonesia which received the report from the victims which are, the integrated service center for the empowerment of women and children, the office of women and children empowerment and protection of mamuju regency, and the National Police of Republic of Indonesia. The Integrated service center for the empowerment of women and children, the office of women and children empowerment and protection of mamuju regency are two institutions belonging to the government whose function is to assist a child victim before the case enters the police. Other than these two institutions there are several more whether it belongs to government or non-government which could assist child victims. These articles will focus on assistance from the government.

The parties that could assist child victims already know about the regulation on how to handle children who are the victim in abuse or crime cases. They have standard procedure operation to make sure that the handling of the case is based on regulation. However, in some cases, for example in the case at East Luwu, the officers have been accused of not handling the case properly from the procedure. Summoning the suspect for the purpose of confirming what the victim has said is the first procedure that they have done improperly. The next stage of this case is reporting to the police that should be assisted by the integrated service center for the empowerment of women and children, but also not have been done. The victim and her family alone reported this case because of the procedure in the integrated service center for the empowerment of women and children working at a slow pace. The uniformed police have been investigating the victim without assistance from her family and social workers or a psychologist. The mother of the victim then asked to sign the police investigation report without the permission of reading it first. This is another procedure that is not done properly.

What must be done if a procedural mistake in handling child cases (especially sexual violence) occurred? What are the punishments given to the officer? The procedure was made so that victims gain protection and follow-up actions. If it weren't done according to procedure and the victim was pressured by several parties, then the institution can be said to have failed to fulfil its responsibilities.

\section{Literature Review}

Based on the data that already collected by Komisi Perlindungan Anak Indonesia (Commission of Indonesia Children Protection), the number of reported cases of Indonesian children who are the victim of sexual abuse in 2020 are 419 reports. The number were increased by $100 \%$ from a year before which there were only 190 reported cases. After 2014 Indonesia was declared in urgency situation on sexual abuse against children, in 2020 was the darker year. 
Not only in Indonesia, sexual abuse against children already happened in all over the world and basically have the same problem: the victim (even the family known about this) do not have the bravery to report. Moreover, when have the bravery to reporting it, it still has the possibility that the report is not process immediately.

Every year, millions of girls and boys around the world face sexual abuse and exploitation. Sexual violence occurs everywhere - in every country and across all segments of society. A child may be subjected to sexual abuse or exploitation at home, at school or in their community. The widespread use of digital technologies can also put children at risk. Most often, abuse occurs at the hands of someone a child knows and trusts.

At least 120 million girls under the age of 20 - about 1 in 10 - have been forced to engage in sex or perform other sexual acts, although the actual figure is likely much higher. Roughly 90 per cent of adolescent girls who report forced sex say that their first perpetrator was someone they knew, usually a boyfriend or a husband. But many victims of sexual violence, including millions of boys, never tell anyone. The braveness of a child (weather a girl or a boy) who is the victim to report is the main key to break down the chain of abusive action. Because of this all resources, including the institution are obligated and work together in maximum to handle the case.

\section{Normative Research: Developing a critical approach}

How should the procedure on handling child sexual victims have been done? If a mistake in the handling procedure occurred, are there any legal consequences? This article was studied through normative research, using statutory regulations, research results, and the opinion of law experts, as well as case progression from credible mass media.

The regulations used to answer these questions are:

i. Law of the Republic of Indonesia Number 11 of 2012 concerning the Juvenile Criminal Justice System

ii. Law of the Republic of Indonesia Number 13 of 2016 concerning Protection of Witness

iii. Regulation of the Minister of Women's Empowerment and Child Protection Number 2 of 2011 concerning Guidelines for Handling Children Victims of Violence

iv. Regulation of the President of the Republic of Indonesia Number 75 of 2020 concerning the Implementation of the Rights of Child Victims and Witness Children

v. Regional Regulation of South Sulawesi Province Number 4 of 2013 concerning Child Protection System

vi. DKI Jakarta Provincial Regulation Number 8 of 2011 concerning Protection of Women and Children from Criminal Acts

vii. Standard Operating Procedures for Handling Complaints from Women and Children Victims of Violence from the Ministry of Women's Empowerment and Child Protection

viii. Standard Operational Procedures of the Indonesian Police regarding Handling and Services of Witnesses and Victims of Violence against Women and Children

\section{Implications}

When handling a criminal case, following regulations is a must. Moreover, a suspect whose interrogation is done improperly according to procedure, for example, without being accompanied by legal counsel, in several cases result in the judge not accepting the public prosecutor's demands (even though this isn't written in criminal law).

There are several institutions that can help accompany a child sexual abuse case. There are institutions owned by the government and non-government. Government institutions are divided into two levels, regional and national. This article focuses on procedure used by regional level institutions at a regional level, because they are usually the quickest for victims to contact. the institution is the integrated service center for the empowerment of women and children dan regional police (Pulungan, 2019; Smith \& Sandhu, 2004; Ilyasa, 2021).

The integrated service center for the empowerment of women and children is a service center integrated in order to protect women and children from discrimination and abuse, including human trafficking, that are made by the government. It can be in the shape of a referral center, business consultation center, reproductive health consultation center, law consultation center, integrated crisis center, integrated service center, trauma center, science and technology information center, shelter, halfway house, or many others. The integrated service center for the empowerment of women and children is a part of office of women's empowerment and child protection which is also at regional level.

The first procedure came from Regulation of the Minister of Women's Empowerment and Child Protection Number 2 of 2011 concerning Guidelines for Handling Children Victims of Violence. Which is used by institutions at national level. Regional Work Unit is related at regional level, public organizations, dan institutions that protect women and children. Complaint handling is a series 
of actions that are done by integrated service providers to follow-up reports on violence against women and children that are submitted by victim, family, or public. The victims they handle are women and children (children are people yet to reach 18, including those still in the womb), but don't ignore the possibility that related reports can come from other parties.

The principles that officers must follow when providing their services to women and children are:

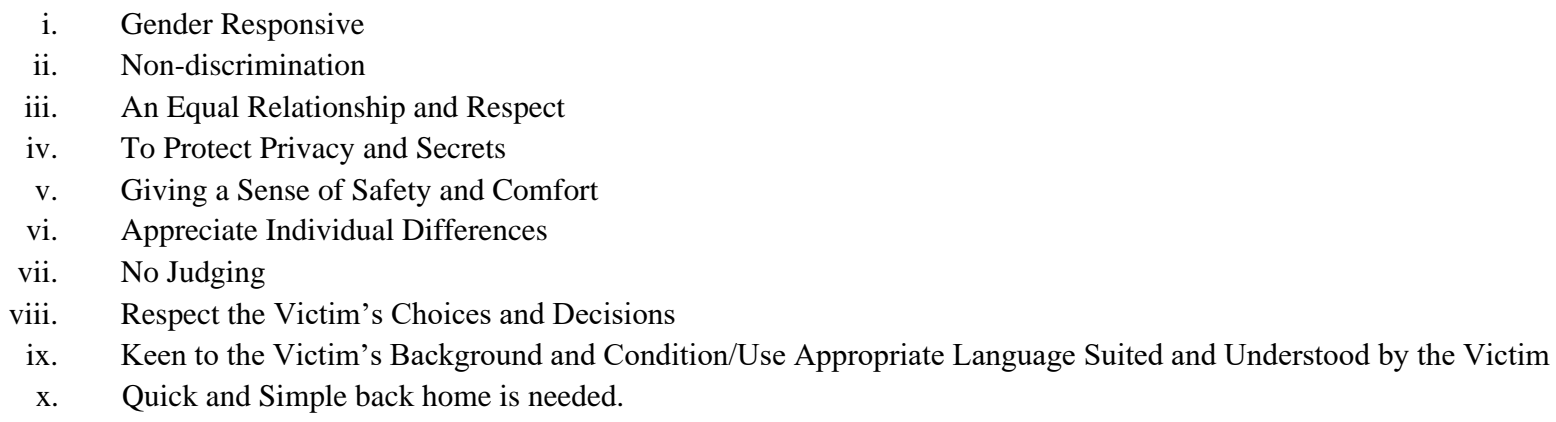

The process of handling a victim as follows:

i. Victim came by themself, either through referral or outreach is identified through screening, assessment, and intervention plan according to the victim's needs.

ii. If the victim was injured then they are given health rehabilitation which includes non-critical service, semi-critical service, and critical service according to their condition as soon as possible. Medical records must be as detailed as possible because it can be used in court.

iii. If victim were not physically injured, and is identified to need psychic counseling, then they are given social rehabilitation which includes a social contract which is an agreement with the victim for agreeing to receive social services, initial counseling, follow-up counseling, clinical assessment, psychosocial therapy, mental and spiritual guidance, accompaniment, home visit as well as resocialization and referral if needed. If the victim is a child, then their agreement or accompaniment is not needed.

iv. If the victim needed legal assistance, it is given after health rehabilitation, social rehabilitation, or directly if the victim needed no rehabilitation. Legal assistance is given starting from police investigation and prosecution at the prosecutor's office until court.

v. The last process in handling the victim is social reintegration, where the victim is reunited with their family to be reaccepted by family and society. This process includes economic and social as well as skill aid in order to receive economic stability, education for victims who were still in school when they became victims a further monitoring and guidance.

vi. PPT's role in social reintegration is monitoring and evaluating as well as reporting on the victim's handling and coordinating with other institutions.

vii. In order to achieve administrative silence and data collection, a form on each step is needed. Every service institution uses a standard form that has been decided beforehand for easy recapitulation.

viii. The whole process isn't free from basic human rights (HAM), avoiding gender discrimination and fulfilling children's rights.

These are kinds of services that will be delivered using handling children as sexual abuse victims.

\section{i. Accusation/Identification}

Accusation/identification service is the first thing to do in this handling process on children as abuse victims to obtain information or to dig the data that needed to give help and this process is a step that influences success from following steps. The purpose of this accusation identification is:

a. To know that the person who is "accused as victim" clearly the victim of abuse or not.

b. To know the problem and the condition of the person who accused as abuse victim that related to physical health, psychic and phycology oh the victim, status, document belonging and self-identity, financial condition, debt-credit, safety condition, also the victim desire which related to the case.

c. To know the need of a person who is accused as abused victim that must be fulfill (temporary place to live if the victim came from outside the region, protection if the victim's safety is threatened, healing, accompany, and home visit, reference, etc.).

d. To make the work of the identification officer easier, it needs facilities that are sufficient, also the availability of identification form in addition the guidance. Identification accusing service is done by the officer that had been trained to identify a person who is accused as the abused victim, know about victim rights, children rights, accept the victim as is, securing client information, non-judging, emphatic and respond on victim condition also the way to make the victim comfortable and trusted to telling the problem that already happened.

\section{ii. Service Mechanism}


a. Identification Accusing Victim: Identification process could happen because of the public participation that has come and acceptable in-service places for victim abuse. After gained the information about there is a child abuse victim, the officer immediately takes a note of the identity of the child completely according to the form which already set.

b. Decide what kind of abuse happened: Based on information/observation that already obtained, it can be decided the child condition whether go through physical or physics abuse.

c. Decided kind of service that needed: Giving reference according to abuse identification. If children went through physical or physics abuse have been referenced to have health, psychosocial rehabilitation, or legal help.

d. Recommendation Following Service: From the result of assessment and following recommendation handling by PPT referrer, then the PPT officer will give intervention recommendation service with the purpose of deciding the best next steps to fulfil victim rights.

e. Coordination with Related Party: After there is following recommendation service and have the deal with the victim, the officer then contacts the following institution service to be coordinated the next step.

f. Administration Identification Process Service: The result of identification in accusing will be submitted in Buku Rekam Kasus (attached) and being admitted together with another supporting document and submitted into computerized system database.

Service that will be given:

\section{Rehabilitation in Health}

Effort on victim health service KTA comprehensively include promotive, preventive, curative, rehabilitative, been done through health service in basic level in "puskesmas mampu tatalaksana kasus KTA" and reference service at hospital that has PPT/PKT or RSUD/RS Bhayangkara. The purpose:

i. Availability health service for children as victim abuse at Health clinic and Hospital that already trained to give service to children as victim abuse.

Reference on medic, medicolegal, and psychosocial for children as victim abuse in Provision and City being done.

ii. Availability separated data on children as abuse victim data in Healt Clinic and Hospital.

\section{Service Mechanism}

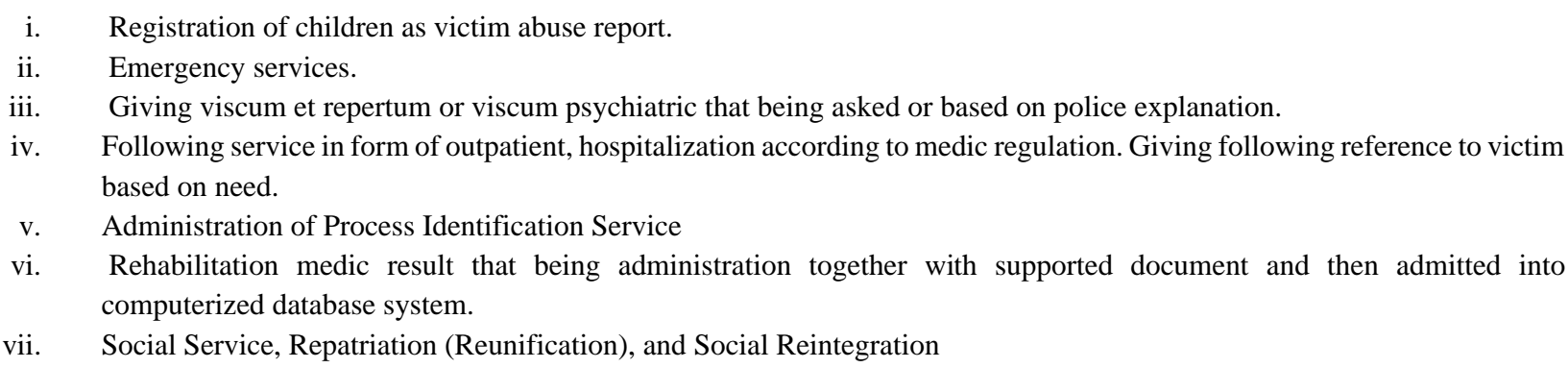

Social rehabilitation is witness and/or victim recovery that has been done by the officer who had been given training to handle children as victim abuse consisting of social worker, counselor, and psychologist that had been trained to handle children as victim abuse from psychosocial harassment condition using psychologic also social help to relieve, protect, and recover physical, psychological, social, and victim's abuse spiritual so being able to continue social function as before.

The purpose:

i. Availability service to recovering psychics victim condition, repatriation (reunification) and social reintegration for children as victim abuse.

ii. Fluffiness children rights as victim abuse for repatriation to reunification with the family.

iii. Availability networking system and reference mechanism to handle children as victim abuse in City.

Social Rehabilitation Mechanism

i. Acceptance of children as victim abuse which had been referred from accusation, as well as the result of reaching.

ii. Disclosure and understanding of the problem.

iii. Intervention planning.

iv. Execution on intervention: the beginning of counseling, the following counseling, psychosocial therapy, mental and spiritual advising, accompany, home visit, resocialization and referred.

Repatriation (Reunification)

Giving back children as victim abuse to his/her family (Reunification) with accompany of accompanies from the police or another accompany by giving transport for victim to back to his/her family or family foster. 


\section{Social Reintegration}

i. On social reintegration, there is process that includes:

ii. Tracing the family member;

iii. preparation process on children as victim abuse and his/her family member;

iv. unity of children with the family/foster family, public/institution;

v. family support in stimulant or psychosocial;

vi. monitoring and evaluation

In this process, the victim will be given several services:

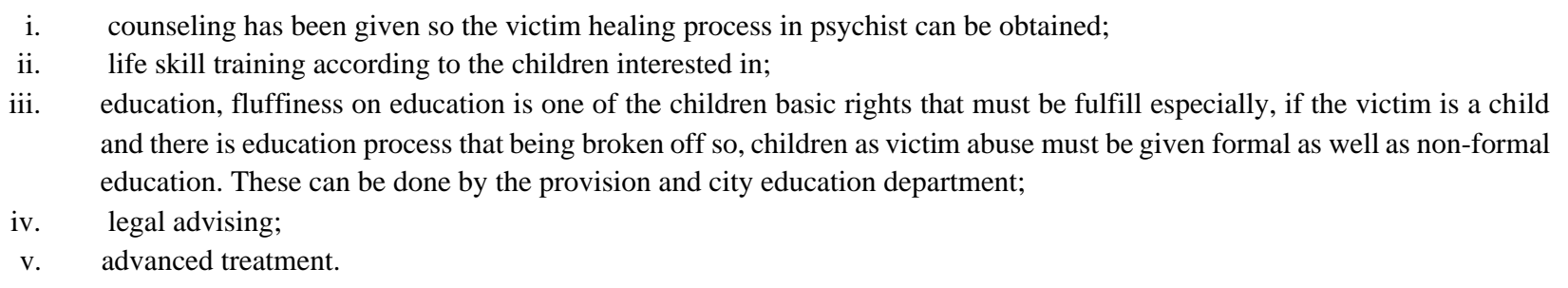

After case identification is clearly categorized as abusive act, next process is legal service/help. Legal service is serial action that is related to handling and protecting children as victim abuse in legal area start from, investigation at the police, accusing in prosecutor, investigation process at court until there is legal certainty. Legal service will be given in order to fulfil the victim and/or witness rights and being done with another service that is already integrated (Mitrović \& Kuprešanin, 2018; Wibowo, 2020).

This legal service is being done by advocate, paralegal/ legal advisor, police officer, persecutor, judge, other party that giving legal service. In addition, there are other legal services, however, not all of it includes legal consultation, legal help, exercise power, represent, accompany, guiding, siding, and doing other legal acts for the law based on other law regulation. The purpose of this service is to give the children victim abuse and witness and/or informant comfort and legal certainty in the form of legal advising.

\section{Service Steps:}

i. Assigned children and witnesses/informant in special room to giving comfort and security.

ii. Assure that child is accompanied by the parents, social worker, NGO, or lawyer.

iii. Obtained children information that will be written on police investigation report.

iv. Gathering evidence that related to the abusive act that happened to children.

v. Publish letter of permission medical check-up and viscum et repetum or viscum psychiatry (VeP).

vi. Coordinate with other institutions concerning victim repatriation back to the family or foster family.

vii. Coordinate with persecutor and published Notice of Commencement of Investigation

viii. Publish Notification of Progress of Investigation Results to informant/family/accompany to know the progress of the case.

ix. Hand over case file to persecutor.

x. Coordinate with the social service/education office/NGO and other institutions to aid children who are victims of violence, both during the examination process in court and out of court.

xi. Appointed officer that has perspective on children.

xii. Deciding court schedule with the consideration of children's education progress.

xiii. Investigating children on court without wearing gowns.

xiv. Conduct trials in the courtroom in a persuasive manner to avoid children.

xv. Prevent children from advancing traumatic suffering

xvi. If the child's psychological condition is not possible, the child will be examined in the courtroom.

xvii. The last attempt and can be taken with other investigations such as regulated in law.

xviii. For children as victim in human trafficking, the persecutor coordinate with the victim or his/her family about restitution if it is the victim or family desired.

xix. Provide a copy of the letter regarding the delegation of the case to the child victim of violence/rapporteur/family/companion.

On that Regulation of the Minister of Women's Empowerment and Child Protection, there is no regulation about legal consequence if there are procedures not carried out.

Any information disclosed in the process of providing services must be kept confidential and known only to people relevant to the provision of services. The officer must convey this principle to the victim. Service providers must ensure that any condition of the victim or information that comes out of the victim will not be judged or judged. The service provider's job is not to make decisions 
for victims but to facilitate victims with information and views to find crystallization of the available options. Sometimes victims come from regions or economic, educational and environmental backgrounds that are not the same as the officers. It must be ensured that the victim is served in a language understood by the victim. The provision of services must be provided immediately without due delay.

Child victims need special protection, including:

i. During the handling process, child victims need to get children's basic rights including the right to education and access to parents

ii. Information that can harm child victims and or their families is not disclosed unless required by law. All steps are taken to protect the privacy and identity of child victims. Names, addresses or other information that may lead to the identification of child victims and or their families, are not disclosed to the public or the media. Permission from child victims should be requested according to their age level before disclosing sensitive information.

All information gained during the process must be kept confidential and known only to relevant figures. The officer must convey the above principles to the victim. They must ensure that regardless of the victim's condition or information that came from the victim they will not be judged. The service provider's duty is not to make decisions for the victim but to facilitate the victim with information and insight to find a crystallization from available options. A victim may sometimes be from a poor economic background or a different education from the officer.

In order to find legal consequences, we need to analyze the higher order that is Law of the Republic of Indonesia Number 11 of 2012 concerning the Juvenile Criminal Justice System. This law begins with the explanation of several terms. Child Victim of a Crime, hereinafter referred to as Child Victim, is a child under 18 (eighteen) years of age who experiences physical, mental, and/or economic loss caused by a criminal act. Community Advisor is a law enforcement functional official who carries out community research, guidance, supervision, and assistance to children inside and outside the criminal justice process. Professional Social Worker is someone who works, both in government and private institutions, who has the competence and profession of social work as well as concern in social work obtained through education, training, and/or experience in social work practices to carry out service tasks and handling children's social problems. Social Welfare Personnel is a person who is educated and trained professionally to carry out service tasks and handling social problems and/or someone who works, both in government and private institutions, whose scope of activities is in the field of Child social welfare. A companion is a person who is trusted by the child to accompany him during the criminal justice process (Ariani, 2014; Pranadita et al., 2021; Aji et al., 2019).

The Juvenile Criminal Justice System is implemented based on the following principles: a. protection; b. Justice; c. nondiscrimination; $d$. the best interests of the Child; e. respect for the opinion of the Child; f. survival and development of children; g. fostering and mentoring children; h. proportional; i. deprivation of liberty and punishment as a last resort; and J. avoidance of retaliation. Every child in the criminal justice process has the right, among others:

i. be treated humanely by considering their needs according to their age;

ii. obtain legal and other assistance effectively;

iii. identity is not published;

iv. obtain assistance from parents/guardians and people who are trusted by the child; and

v. get social advocacy (Liyus, 2020; Ariani 2014).

The following is the procedure for handling cases of children (including child victims) and the provisions that include the legal consequences:

i. Based on Article 18 Law of the Republic of Indonesia Number 11 of 2012 concerning the Juvenile Criminal Justice System, in dealing with children's cases, Social Advisors, Professional Social Workers and Social Welfare Workers, Investigators, Public Prosecutors, Judges, and Advocates or other legal aid providers must pay attention to the best interests of the Child and strive to maintain a family atmosphere. Officials or officers who violate this provision are subject to Administrative Sanctions.

ii. Based on Article 19, the identity of the Child, Child Victim, and/or Child Witness must be kept confidential in the news in print or electronic media. Identity includes the name of the Child, the name of the Child Victim, the name of the Child Witness, the name of the parent, address, face, and other matters that may reveal the identity of the Child, Child Victim, and/or Child Witness. Everyone who violates is subject to Criminal Sanctions.

iii. Based on Article 22 Investigators, Public Prosecutors, Judges, Community Counselors, Advocates or other legal aid providers, and other officers in examining cases of Children, Child Victims, and/or Child Witness do not wear toga or official attributes. There are no sanctions for violations of this provision.

iv. At each level of examination, the Child must be given legal assistance and accompanied by a Community Counselor or other companion in accordance with the provisions of the legislation and must be accompanied by a parent and/or person trusted by the Child Victim and/or Child Witness, or Social Worker. If parents are suspects or defendants in a case being examined, this provision does not apply to parents. There are no sanctions for violations of this provision. 
v. Investigations of children's cases are carried out by investigators who are determined based on Decision of the Head of the

National Police of the Republic of Indonesia

or other officials appointed by Head of National Police of Republic of Indonesia. Examination of the Child Victim or Child Witness is carried out by an Investigator who meets the following requirements:

i. has already experienced as investigator;

ii. has an interest, attention, dedication, and understanding about children's problem;

iii. has already attended technical training on juvenile justice

If there are no investigators who meet the requirements above, the investigation task is carried out by the investigator who carries out the task of investigating criminal acts committed by adults. There are no sanctions for violations of this provision.

In investigating a child's case, the investigator is obliged to ask for consideration or advice from the community advisor after the crime has been reported or reported. If deemed necessary, the Investigator may seek consideration or advice from educational experts, psychologists, psychiatrists, religious leaders, Professional Social Workers or Social Welfare Workers, and other experts. In the case of conducting an examination of the Child Victim and the Child Witness, the Investigator is required to request a social report from the Professional Social Worker or Social Welfare Personnel after the crime has been reported or reported. Officials or officers who violate this provision are subject to Administrative Sanctions.

Child victims are entitled to all protection and rights regulated in the provisions of the legislation. In addition to the rights that have been regulated in the provisions of laws and regulations, child victims have the right to medical rehabilitation and social rehabilitation efforts, both within the institution and outside the institution; guarantee of safety, whether physical, mental, or social; and easy access to information regarding the progress of the case.

Based on the considerations or suggestions of the social advisor, professional social workers or social welfare workers or investigators may refer the victim's child to the agency or institution that handles child protection or child social welfare institutions. If the child victim requires immediate relief measures, the investigator, without a social report from the professional social worker, may directly refer the child victim to a hospital or institution that handles child protection in accordance with the condition of the child victim.

Based on the results of community research from community counselors and social reports from professional social workers or social welfare workers, children, child victims, and/or child witnesses are entitled to medical rehabilitation, social rehabilitation, and social reintegration from the institution or agency that handles child protection. Child victims and/or witness children who need protection can obtain protection from institutions that handle witness and victim protection or social protection houses in accordance with the provisions of the legislation.

The Police have standard operating procedures for handling and services for witnesses and victims of violence against women and children. Based on the SOP, the handling and services of child victims are carried out together with related elements which include health services, special handling related to the confidentiality of victims, assistance by social workers and legal assistance at every level of the examination process, spiritual guidance services. Protection of women and children is all efforts aimed at providing a sense of security to victims carried out by families, advocates, social institutions, police, prosecutors, courts or other parties, either temporarily or based on a court order. Temporary protection for women and children is protection that is directly provided by the police and/or social institutions or other parties, prior to the issuance of a protection order from the court.

Officer that placed in Women and Children Unit Service prepared person with the criteria:

i. The attitude of the investigators and assistant investigators in the handling and service of victims must be neat in appearance and attire.

ii. Has sufficient knowledge about criminal law especially, the law of PKDRT, Children Protection and Trafficking also other law

Steps in handling/servicing women and children by the police:

i. Deliver victim to nearest health centre for a viscum

ii. Taking descriptions

iii. Offer to contact a counsellor or help

iv. Inspection takes place in a comfortable and secretive place

v. Provide information on related law to victim

vi. Give victim a notification of the progress of the investigation

Indonesia also has Law Number 13 of 2006 concerning Protection of Witnesses and Victims. Witness and victim protection is principled on appreciating human honor and dignity, sense of security, fairness, non-discrimination, and legal certainty. Witness and victim protection aims to give a sense of security to victims/witnesses in the process of giving testimonies.

According to chapter 5, victims and witnesses are entitled to: 
i. Individual, familial, and possession protection, as well as freedom from threats that are related to their former, current, or future testimony;

ii. Participate in choosing and deciding the shape of protection and security support;

iii. Testimony without pressure;

iv. Translator;

v. Free from ensnaring questions;

vi. Receive information on the case's progress;

vii. Receive information on the court's decision;

viii. Know when prisoner is released;

ix. Receive new identity;

x. Receive new residence

xi. Receive transportation compensation according to need;

xii. Legal counsel; and/or

xiii. Receive living expenses assistance until protection ends.

The rights above are given to witnesses and victims until the end of the protection period according to the decision of Witness and Victim Protection Agency. This article does not discuss the regulation further because witnesses and victims with protection are witnesses and victims that have been deemed in need of protection by Witness and Victim Protection Agency.

\section{Conclusions}

Based on discussion, institution in Indonesia already have guidance/procedure to handle children as victim abuse. The guidance included the principal, the rights of children as victims, witness rights, and handling procedure. Administrative punishment and crime punishment for law enforcers who did not follow the procedure, listed in Law of the Republic of Indonesia Number 11 of 2012 concerning the Juvenile Criminal Justice System.

For the case in East Luwu, it can conclude that in a normative way, there is no legal consequence for these actions:

i. The Integrated Service Center For The Empowerment Of Women And Children brought together expected perpetrator with reporter and children as victim

ii. Investigation victim physiology with non-psychological officer

iii. The Integrated Service Center For The Empowerment Of Women And Children did not accompany when reporter and victim went to East Luwu Police

iv. The Integrated Service Center For The Empowerment Of Women And Children did not suggest reporter to has legal advisor

v. East Luwu Police investigated their victim with uniform, without accompany of their mother, legal advisor, social worker, or psychologic

vi. East Luwu Police asked the mother of victim to sign police investigation report and prohibited her to read it first

vii. East Luwu Police investigated the children victim in health care and Bhayangkara Hospital without accompany

The action that has normative sanction just only the obligation to securing the identity of victim which East Luwu Police did not so, the public had known the identity of the victim and the person who report the case. This action can cause crime sanction for the officer. However, at the end, there is no process until now.

Indonesia already has regulation related on child protection especially, child as victim abuse weather in national or in regional. However, in the regulation there is no guaranty that child rights as victim abuse must be fulfill because of there is no punishment or legal consequences in Law of the Republic of Indonesia Number 11 of 2012 concerning the Juvenile Criminal Justice System or other regulation. If there is a mistake from the procedure handling child victim, there are only several mistakes that have legal effect on administrative sanction and crime sanction. It's difficult to ensure that the rights of the victims are fulfilled or procedures are carried out properly.

Author Contributions: Conceptualization, F., ASP., EHH.; Methodology, F., ASP., EHH.; Data Collection, F.,ASP., EHH.; Formal Analysis, F.,ASP., EHH.; Writing - Original Draft Preparation, F., ASP., EHH.; Writing—Review And Editing, F.,ASP., EHH.;All authors have read and agreed to the published the final version of the manuscript.

Institutional Review Board Statement: Ethical review and approval were waived for this study, due to that the research does not deal with vulnerable groups or sensitive issues.

Data Availability Statement: The data presented in this study are available on request from the corresponding author. The data are not publicly available due to privacy.

Conflicts of Interest: The authors declare no conflict of interest.

\section{References}

Aji, W. S. (2019). The Implementation of Diversion and Restorative Justice in the Juvenile Criminal Justice System in Indonesia. Journal of Indonesian Legal Studies, 4(1), 73-82. 
Ariani, N. V. (2014). Implementation of Law Number 11 of 2012 concerning Children's Criminal Justice System in an effort to protect children's interests. Law media journal, 21(1), 16-29.

Chan, K. L. (2009). Sexual violence against women and children in Chinese societies. Trauma, Violence, \& Abuse, 10(1), 69-85.

Daniati, H. A., Sailan, M., \& Mannayong, J. (2021). Institutional Revitalization of Integrated Service Centers for the Empowerment of Women and Children: Evidence from Indonesia. Psychology and Education Journal, 58(5), 2608-2616.

Ghania, A. S., \& Lathifah, N. (2022). The winner of the police news handled the case of a childhood violence in East Luwu Pala Voice. com and tirto. Indo. JISJIP (Journal of Social and Education),6 (1), 1-13.

Ilyasa, R. M. A. (2021). Legal and Victimological Perspective on Sexual Violence against Children Cases in Indonesia. The Indonesian Journal of International Clinical Legal Education, 3(3), 281-300.

Liyus, H. (2020). Legal Protection for Children Victims of Rape Comparative Study Between Indonesia and Malaysia. Advances in Social Science, Education and Humanities Research, 442, 6-11.

Marbun, V. M., Purba, R. C., \& Rahmayanti, R. (2020). Juridical Analysis of the Crime of Harassment Performed by Adults on Minors Based on Law Number 35 of 2014. Binamulia Hukum, 9(2), 107-114.

Mitrović, L., \& Kuprešanin, J. (2018). Justice for children in justice system of bosnia and herzegovina-reflection on european law in area of human rights. EU and comparative law issues and challenges series (ECLIC), 2, 169-183.

Pranadita, N., Rahayu, A., \& Wibowo, L. A. (2021). Strategic Management Implementation by Advocates related to the Law of the Republic of Indonesia Number 11 of 2012 concerning the Children's Justice System Children. MEA Scientific Journal (Management, Economics \& Accounting), 5(1), 1616-1631.

Pulungan, M. S. (2019). Strategy For Integrated Service Center For Women Empowerment And Children Protection In Children Prevention. Tazkir: Jurnal Penelitian Ilmu-ilmu Sosial dan Keislaman, 5(2), 253-270.

Smith, D. C., \& Sandhu, D. S. (2004). Toward a positive perspective on violence prevention in schools: Building connections. Journal of Counseling \& Development, 82(3), 287-293.

Wibowo, S. A. (2020). Child Sexual Violence and the Violation of Human Rights: The Darkest Side of Law Enforcement in Indonesia. The Indonesian Journal of International Clinical Legal Education, 2(4), 421-434.

Wuriani, N. I. (2021). Tagar activism \# PercumalaporPolisi as Zeitgeist Siber Democracy in Indonesia. Wacana: Communication Science Science Journal, 20(2), 171-183.

Zambon, M. P., Jacintho, A. C. D. Á., Medeiros, M. M. D., Guglielminetti, R., \& Marmo, D. B. (2012). Domestic violence against children and adolescents: a challenge. Revista da Associação Médica Brasileira, 58, 465-471.

Publisher's Note: SSBFNET stays neutral with regard to jurisdictional claims in published maps and institutional affiliations.

\section{(c) (1)}

(C) 2022 by the authors. Licensee SSBFNET, Istanbul, Turkey. This article is an open access article distributed under the terms and conditions of the Creative Commons Attribution (CC BY) license (http://creativecommons.org/licenses/by/4.0/).

International Journal of Research in Business and Social Science (2147-4478) by SSBFNET is licensed under a Creative Commons Attribution 4.0 International License. 